

UDC 338.439:006.83

\title{
Main requirements for food safety management systems under international standards: BRC, IFS, FSSC 22000, ISO 22000, Global GAP, SQF
}

\author{
M. Ya. Bomba, N. Ya. Susol \\ Lviv Institute of Economics and Tourism, Lviv, Ukraine
}

Article info

Received 24.01.2020

Received in revised form 25.02.2020

Accepted 26.02.2020

Lviv Institute of Economics and Tourism, Lesya Ukrainka Str., 39, Lviv, 79008, Ukraine.

Tel.:+38-067-947-68-31

E-mail:susn@ukr.net
Bomba, M. Ya., \& Susol, N. Ya. (2020). Main requirements for food safety management systems under international standards: BRC, IFS, FSSC 22000, ISO 22000, Global GAP, SQF. Scientific Messenger of Lviv National University of Veterinary Medicine and Biotechnologies. Series: Food Technologies, 22(93), 18-25. doi: 10.32718/nvlvet-f9304

The research analyzed the international standards basic requirements structure: BRC, IFS, FSSC 22000, ISO 22000, Global GAP, SQF for food safety management systems that realize principles of the HACCP concept. A comparative analysis of the international standards basic requirements for food safety management systems has identified that the requirements structure is identified as an interconnected set of rules, system-structured processes for the purposeful prevention of hazard risks at certain stages or in the food business. The main differences between the standards are in the modification of approaches to the implementation of the HACCP principles, the interpretation of the basic concepts and definitions, the detailed requirements, the application of their own programs of the processes and procedures identification that allow to ensure that the results correspond to the set task. Other differences in standards are at the level of system-elemental, structural, and functional components. Standards have the same goals, so their requirements are similar and have a certain level of identity, much of the difference is at the audit level, which uses different levels, system points and categories. The requirements of all standards are structured and differentiated into mandatory and recommended blocks, which enables companies to gradually implement changes. IFS, FSSC, ISO standards have high level structure (HLS), which is common basis for ISO standards that greatly simplifies the integration of several systems simultaneously in monitoring, action adjustments, audit processes. The GlobalGAP standard requirement system, unlike other considered ones, has a narrow target, which has provided a detailed description, for tracking, a set of indicators for quality and safety including genetically modified organisms and allergens, however, it is compatible with others. Taking into account the globalization of markets conditions in analyzing the international standards requirements, their correlation with global safety-related criteria such as: implementation of the HACCP principles, recognition of the standard GFSI, providing traceability principles and mechanisms and prerequisites for programs (PRP), validity of the certificate, coherence of processes in the creation of integrated systems with standards ISO 9001, ISO 14001, OHSAS 18000.

Key words: standards, requirements, HACCP, BRC, IFS, FSSC 22000, ISO 22000, Global GAP, SQF, food safety management system, safety and quality.

\section{Основні вимоги до систем управління безпечністю харчової продукції за міжнародними стандартами: BRC, IFS, FSSC 22000, ISO 22000, Global GAP, SQF}

\author{
М. Я. Бомба, Н. Я. Сусол \\ Львівський інститут економіки і туризму, м. Львів, Украӥна
}

У иьому дослідженні проаналізовано структуру базових вимог міжнародних стандартів: BRC, IFS, FSSC 22000, ISO 22000, Global GAP, SQF до систем управління безпечністю харчової продукиії, щчо реалізують принципи кониепиії НАССР. Порівняльний аналіз базових вимог міжнародних стандартів на системи управління безпечністю харчової продукиї визначив, щю структура 
вимог ідентифікується, як взаємопов'язана сукупність правил, системно структурованих процесів для иілеспрямованого попередження ризиків небезпечності на певних стадіях або в галузях харчової діяльності. Основні відмінності стандартів полягають у модифікації підходів реалізації принципів НАССР, трактуванні основних понять і визначень, деталізації вимог, застосуванні власних програм ідентифікацї процесів і процедур, які дозволяють забезпечувати відповідність результатів поставленому завданню. Інші відмінності стандартів знаходься на рівні системно-елементних, структурних, функціональних компонентів. Стандарти мають однакові иілі, тому їх вимоги є схожі і мають певний рівень ідентичності, при иьому значна частина відмінностей знаходиться на рівні аудиту, де застосовують різні рівні, системи балів і категорій. Вимоги усіх стандартів структуровані та диференційовані на блоки обов'язкових та рекомендованих, щзо дає можливість компаніям поступово впроваджувати зміни. Стандарти IFS, FSSC, ISO мають високорівневу структуру (HLS), яка є спільною основою для стандартів ISO, щзо значно спрощує інтегрування декількох систем водночас в процесах: моніторингу, коригуванні дій, аудиту. Система вимог стандарту GlоbаlGAP, на відміну від інших розглянутих, має вузьке иңільове призначення, шзо забезпечило детальний опис, для відстеження, комплексу показників щуодо якості та безпечності, включаючи генетично модифіковані організми і алергени, втім вона є сумісна з іншими. 3 огляду на умови глобалізаиї ринків в аналізі вимог міжнародних стандартів досліджено їх співвідношення за глобальними критеріями гарантування безпечності, такими як: реалізачія принципів НАССР, визнання стандарту GFSI, забезпечення принципів та механізми простежуваності і програм-передумов (PRP), термін дії сертифікату, взаємоузгодженість процесів в створенні інтегрованих систем із стандартами ISO 9001, ISO 14001, OHSAS 18000.

Ключові слова: стандарти, вимоги, НАCCP, BRC, IFS, FSSC 22000, ISO 22000, Global GAP, SQF, система управління безпечністю харчової продукиії, безпечність та якість.

\section{Introduction}

Formulation of the problem. The introduction of a new food safety control system in Ukraine, equivalent to the European system, determines the mandatory application of the principles of the HACCP system. (Hazard Analysis and Critical Control Point) (Pro osnovni pryncypy ta vymogy do bezpechnosti ta jakosti harchovyh produktiv, 1997; Reglament JeS 178/2002). The law of Ukraine "On main principles and requirement for safety and quality of foodstuffs" obliges all food market operators since September 2016 to implement the prerequisite programs, and after procedures based on the principles of the HACCP system. However, for implementation of HACCP procedures, transition periods are envisaged that enable market operators to reorient to new requirements and, if necessary, to bring food production in line with the provisions of the new Law. The deadline for all transitional periods is 20.09. 2019. As known, in international practice on food safety management systems according to HACCP principles, there are many standards, the most common of them are: BRC, IFS, Global GAP, ISO 22000, SQF. In Ukraine the food sector generally applies the requirements of the standard ISO 22000, in a significant minority, FSSC 22000 and Global GAP. Integration into the global food market of domestic producers prompts to focus on the requirements of international standards, which also actualizes the study of their requirements, in order to provide a more complete picture of possible approaches to guarantee the food products safety at all stages of the food chain.

Analysis of recent research and publications. The signing of the Association Agreement resulted in a significant increase in the interest of Ukrainian scientists and experts in the study of European norms on food safety and the analysis of approaches to the development of a food safety management system in the EU and Ukraine (Tolok, 2015; Kushwah \& Kumar, 2017; Vorobiov et al., 2019). In the scientific environment these issues are investigated both in economic, technical and legal aspects, and we distinguish the works of such scholars: Yu. V. Slyva, M. Ya. Gavrylyak, Yu. D. Bilyka, V. V. Brulevych, Yu. V. Didok, V. M. Kryvoshei,
N. I. Cherevychna, I. G. Vlasenko, A. O. Levytska, M. P. Ostapyuk. An overview of international standards and regulations on the management of safety and quality in the food industry was carried out in works (Jageljuk \& Cydoruk, 2015; Himicheva et al., 2015; Kuzoma \& Pavliuk, 2019). The mentioned publications contain the types of standards and legal norms, expediency of their application in the development of safety management systems, and only their requirements are considered partly. Therefore, there is a need to carry out a comprehensive analysis of the structure, requirements and additional clarifications of international standards that can be applied in the practice of national enterprises.

The aim of the article is study of the international standards basic requirements: BRC, IFS, FSSC 22000, ISO 22000, Global GAP, SQF to food safety management systems in order to develop an understanding of international food safety management practices based on HACCP principles, to help eliminate technical barriers in international trade and protect the social and economic interests of consumers.

\section{Materials and methods}

The theoretical and informational basis for analytical research was the international standards on food safety management systems, regulatory acts, scientific publications and Internet resources on the subject. The research was conducted using methods of systematic, content and comparative analysis, synthesis and logical generalization.

\section{Overview of international standards}

Modern food safety management systems which are authoritative in progressive international practice, are, in one way or another, based on the principles of HACCP. The HACCP concept was developed by "Pillsbury", commissioned by the US Army Laboratory and the National Aeronautics and Space Administration (NASA) to prevent the formation of toxins in food products intended for astronauts. At the heart of the HACCP concept there are seven principles that provide the necessary level of safety indicators in the process of its production, control at critical points in the technological process, where there may be a threat of the dangerous factors appearance. The 
system allows to distinguish all potentially dangerous factors in the food product and to prevent them from occurring. In the mid 80's the National Academy of Sciences of the United States suggested the use of the HACCP system in the food industry (Hulebak \& Schlosser, 2002).

Legislation of the EU countries, Canada, the USA, Australia, Japan, which approved the mandatory application of systems based on HACCP principles, is flexible enough and allows modifications to the implementation, depending on the scale, kind and nature of the production activity.

In the EU current Regulation № 852/2004 establishes a mandatory system for food business operators based on the principles of HACCP and procedures designed to ensure the safety of food products (Shhodo gigijeny harchovyh produktiv, 2004). Based on the concept of HACCP many standards have been developed which are applied in different countries, regions or corporate associations. Among the most commonly used food safety management practices in the United States are the following standards: BRC, IFS, GLOBAL GAP, FSSC 22000, ISO 22000, Datch HACCP, SQF. In addition to the others mentioned, there are more than 400 certification systems for agricultural products and food products only in the EU. At the first glance, it seems that the application of the common principles does not leave possibility for numerous variations in the requirements, but considering the peculiarities of all the individual parts of the food chain, approaches to the principles application will have significant peculiarities. These standards operate on a voluntary basis belonging to the "private" group as their developers are individual companies, associations and nongovernmental organizations.

The requirements of the private standards are designed to improve the safety guarantees, so a large part of the rules has more meticulous implementation of the norms, and some standardized indicators have more restrictive limits, higher levels and edges. This approach does not exclude the prioritization of national legislation in any way, and there is an increased competitive market requirements.

BRC (British Retail Consortium) is a global standard designed to evaluate compliance with suppliers of their own commercial brands of retail chains in the UK. All enterprises in any country that supply products on the BRC network must comply with this standard. BRC Global Standard - Food consists of seven parts and sets the following requirements to the manufacturer:

- development and introduction of the system of dangerous factors and critical control points analysis at the enterprise (HACCP);

- availability of documented and effective quality management system;

- control of production standards, products, processes and personnel.

BRC Certification assists manufacturers, company owners and sellers in complying with legal requirements to ensure consumer safety. The standard has a wide scope of application, including all aspects of food safety and requirements both for suppliers and sellers. BRC Global Standards are currently the main requirement of leading retailers, manufacturers and organizations that sell food products. They require the development of an effective program for risk and critical control points analysis, the fulfillment of requirements for all production processes, including the management of allergens, the origin of the product and ingredients, the packaging of products, and the methods of testing them, iafe control of processes establishing and maintaining, equipment calibrating and implementing a HACCP document plan (About BRC Global Standards, 2018).

IFS standards (International Food Standard) is a set of requirements concerning food products and services safety. There are the following objectives of IFS standards:

- creation of an assessment base for all suppliers of a trading network;

- the only form of audit and mutual recognition of its results;

- absolute comparability of results within the network of suppliers.

IFS certificates prove that companies produce products and provide services that meet customer requirements, and are constantly working to improve processes. The main focus is on food safety and the main and auxiliary processes quality. The IFS Food standard is important for all food manufacturers, especially for those who produce private labels, because it contains many requirements for customer compliance (International Featured Standards, 2018).

The development of the sixth edition of the IFS standard involved retailers from France, Germany, Italy, Switzerland and Austria. Such consolidated cooperation has become a guarantee of high results and development of partnership cooperation.

Global GAP (GAP Good Agricultural Practice) is a program launched by retailers in Europe to ensure safe food and ornamental plants production. The primary objective of the GLOBAL GAP certification is to confirm that food products are safe and do not harm the health of consumers and workers and that the technology of production does not harm the environment. Global G.A.P. standard determines the risk assessment of possible microbiological hazards at the following control points: management of the site (object); hygiene of labor; organic fertilizers; water quality; Sanitary and hygienic standards during harvesting. Global GAP is an integrated standard for primary products with the possibility of using its individual modules for various product groups - from plant to animal production. The Global G.A.P system operates on the basis of control points, that is, it defines a list of points that must be performed by the manufacturer to be certified. The structure of the Global GAP standard has 236 control points, which are differentiated as follows: 74 main ones (highlighted in red colour); 125 secondary ones (highlighted in yellow colour); 37 recommendations (highlighted in green colour) (GLOBAL G.A.P., 2018). One quarter of control points Global G.A.P. regulates the use of pesticides and fertilizers to be permitted used in accordance with the rules, all actions are registered.

The METRO cash \& carry sales network successfully motivates Ukrainian farmers to work on the Global G.A.P. standards and product certification. Since 2014 the 
Global G.A.P certification is obligatory for local farmers who supply products to the trading network. At the same time, support is provided to farmers by METRO cash \& carry companies concerning consulting and educational issues and certification.

FSSC 22000 (Food Safety System Certification) is an international certification scheme for food safety management system based on HACCP principles, international standard ISO 22000:2005 and BSI-PAS 220:2008, requirements for programs-prerequisites ISO/TS 220021:2009 "Prerequisite programmes on food safety - Part 1: Food manufacturing”, ISO/TS 22002-2:2013 "Prerequisite programmes on food safety - Part 2: Catering", ISO/TS 22002-4:2013 "Prerequisite programmes on food safety - Part 3: Food packaging manufacturing", ISO 19011 and 5 additional requirements of the application 1A: FSSC 22000 (Legal status of FSSC 22000, 2018). As FSSC 22000 system is based on ISO 22000 standards, then it simplifies integration with other management systems such as: ISO 9001, ISO 14001 and OHSAS 18001, which enables food enterprises to guarantee the safety of food products as well as to improve the environmentally friendly, professional and occupational safety and health conditions.

Certification scheme FSSC 22000 is managed by independent private structure Foundation for food safety certification founded in the Netherlands. In 2016 version 4 FSSC 22000 was issued, which includes requirements for catering services, retail, transportation and storage. The FSSC 22000 certifies the level of product safety at the international level through a comprehensive management system that meets the requirements of food safety regulatory authorities.

ISO 22000:2005 standard has requirements for a food safety management system, according to which the organization must demonstrate its ability to control the hazards of food products in order to guarantee the safety of products at the time they are consumed by a human. The standard was designed to cover all food chain processes and rational integration with the standard ISO 9001 "Quality Management Systems". The requirements of ISO 22000 standard can be applied by all organizations directly or indirectly involved at different levels in the food chain processes (production, processing, storage, supply, distribution, retailing). In 2017 the ISO / TC 34 / SC 17 Committee approved the new version of ISO 22000: 2017 which applied the new high-level structure of ISO (HLS), which is the common basis for all management system standards (ISO/TC 34/SC 17, 2018). This structure simplifies the integration of several control systems in processes that take place at a certain time. Also the key terms were clarified, a new understanding of the concept of "a risk" was defined. Risk is a vital concept for the food industry enterprise, with the notion of risk at the operational level (using the Hazard Analysis Critical Control Point HACCP approach) and risk at the strategic level of the management system (business risk) with its ability to use opportunities to achieve specific business goals (ISO 22000 revision Why was ISO 22000 revised?).

$\mathrm{SQF}$ is an international system of standards concerning safety and quality of bfood products managed by
Food Marketing Institute FMI, the USA. The system is based on the principles of managing the network of suppliers in the production of raw materials, production and distribution of food products. The SQF requirements include the use of HACCP principles for controlling food safety risks and food quality. Implementation of the system is topical for suppliers of local and global food markets.

The SQF Code of requirements is unique in that it has three levels of certification that demonstrates a certain stage in the development of a food safety and quality management system. The level structure of the SQF standard allows it to be applied to enterprises that are at different stages of the implementation of the management system, while the standard takes into account the specifics of each particular industry. There are three levels of SQF certification system:

- basics of food products safety;

- certification of food safety plans based on HACCP;

- complex systems of food products quality and safety.

Certification of products according to these standards emphasizes the requirements for the systematic application of the HACCP principles and the CODEX Alimentarius Food Inspection Commission guidelines. The Gluten-Free Certification Partnership Program (GFCP) is also being developed. For the development of competent SQF implementation practices, SQF licensed consultants are currently operating and there are currently training centers licensed at the international level in the USA, Australia, Canada and Mexico.

\section{Results and discussion}

To study the structure and requirements of international standards for food safety management systems and their certification schemes, six norms have been adopted that allow the implementation of the principles of the HACCP concept and are the most common in practice in many countries of the world. Table 1 provides a comprehensive overview of the international standards basic requirements structure for food safety management systems and their certification.

A comparative analysis of the structure of the basic requirements of international standards for food safety management systems has allowed to identify common features and structural differences, namely:

- The structure of the requirements of all standards is identified as an interconnected set of rules, systemstructured requirements and recommendations for purposeful prevention of hazard risks at all stages, "from the field to the table" or specialized programs for a certain stage of production;

- the essence of the system approach used in the development of standards is common, the differences appear at the level of system-elemental, -structural, functional components as well as the interpretation of the basic concepts and definitions, formulation and detailed requirements; 
Table 1

Basic requirements of international standards for food safety management systems structure

\begin{tabular}{|c|c|c|}
\hline ls & Standard structure, basic requirements & $\begin{array}{l}\text { Target purpose standard / country } \\
\text { applying standard }\end{array}$ \\
\hline $\begin{array}{c}\text { BRC } \\
\text { (British Retail } \\
\text { Consortium Global } \\
\text { Standard) }\end{array}$ & $\begin{array}{l}\text { BRC Global Standard - Food consists of seven chapters: } \\
\text { 1. Commitments of top management and continuous } \\
\text { improvement; } \\
\text { 2. Food safety plan - HACCP; } \\
\text { 3. Food safety scheme and quality management; } \\
\text { 4. Standards for the location of production facilities and } \\
\text { requirements for the production environment; } \\
\text { 5. Product control; } \\
\text { 6. Processes control; } \\
\text { 7. Personnel (requirements for personnel) }\end{array}$ & $\begin{array}{l}\text { It covers the production of food } \\
\text { products, packaging and packaging } \\
\text { materials, storage and delivery of } \\
\text { products. } \\
\text { It is applied in more than } 130 \\
\text { countries, mostly in the EU and the } \\
\text { USA. }\end{array}$ \\
\hline $\begin{array}{c}\text { IFS } \\
\text { (International Food } \\
\text { Standard) } \\
\text { international } \\
\text { food standard }\end{array}$ & $\begin{array}{l}\text { The structure of IFS requirements correlates with the structure of } \\
\text { ISO } 9001 \text { and includes } 6 \text { sections: } \\
\text { 1. Responsibility of the management; } \\
\text { 2. Quality and safety management system (HACCP system, } \\
\text { quality guidance); } \\
\text { 3. Resource management (human resources, hygiene, residential } \\
\text { premises, etc.); } \\
\text { 4. Planning and production processes (product development, } \\
\text { production equipment, traceability, etc .; } \\
\text { 5. Measurement, analysis, improvement (control, product recall, } \\
\text { etc.). } \\
\text { 6. Product protection and external inspections. }\end{array}$ & $\begin{array}{l}\text { It covers the production of food } \\
\text { products (excluding primary one), } \\
\text { supply and retail at all stages, } \\
\text { labeling and product packaging. } \\
\text { It is applied in almost } 90 \text { countries, } \\
\text { is mostly used in Germany, France, } \\
\text { Austria, Poland, Sweden, Spain, } \\
\text { Italy. }\end{array}$ \\
\hline $\begin{array}{r}\text { Globa } \\
\text { Globa } \\
\text { agricultur } \\
\text { GLOBA }\end{array}$ & $\begin{array}{l}\text { The standard (program) contains the following sections of the } \\
\text { requirements: } \\
\text { 1. Labor protection and industrial sanitation; } \\
\text { 2. Environmental protection; } \\
\text { 3. Analysis of production risks; } \\
\text { 4. Procedure for reviewing complaints; } \\
\text { 5. Procedures for tracking and returning products; } \\
\text { 6. Origin and quality of seed material; } \\
\text { 7. Suitability of soils for agricultural production; } \\
\text { 8. Soil analysis and adequacy of the developed fertilizer system; } \\
\text { 9. Compliance of the applied system of plant protection - } \\
\text { introduction of an integrated system of protection; } \\
\text { 10. Condition and correctness of the measures taken on cleaning, } \\
\text { refinement and storage of products. }\end{array}$ & $\begin{array}{l}\text { The main purpose of Global G.A.P. } \\
\text { for agriculture is the following: } \\
\text { - plant growing; } \\
\text { - animal husbandry; } \\
\text { - breeding of aquatic animals and } \\
\text { plants. } \\
\text { Global G.A.P works in over } 100 \\
\text { countries. Most certified } \\
\text { manufacturers are in Italy, Spain } \\
\text { and the Netherlands. }\end{array}$ \\
\hline FS & $\begin{array}{l}\text { The standard for certification of food manufacturers which } \\
\text { combines the requirements of ISO 22000: } 2005 \text { and PAS 220: } \\
2008 \text {. } \\
\text { Current standard: FSSC 22000: 2011. "Certification Scheme for } \\
\text { food safety systems according to ISO 22000: } 2005 \text { and BSI-PAS } \\
\text { 220: 2008". In the description of the FSSC } 22000 \text { scheme, the } \\
\text { requirements and rules are structured as follows: } \\
\text { Part 1. Requirements for organizations that intend to be certified. } \\
\text { Part 2. Requirements and rules for certification bodies. } \\
\text { Part 3. Requirements and rules of accreditation. } \\
\text { Part } 4 \text {. Rules for the management consisting of representatives } \\
\text { of interested parties }\end{array}$ & $\begin{array}{l}\text { It covers the production of food } \\
\text { products, services in the sphere of } \\
\text { catering, retail, transportation and } \\
\text { storage. } \\
\text { It is applied in more than } 140 \\
\text { countries around the world. Mostly } \\
\text { in the EU, as well as in China, } \\
\text { India, Canada, Greece, Romania, } \\
\text { Turkey, Russia, Ukraine and some } \\
\text { African countries. }\end{array}$ \\
\hline HACCPISO 22000 & $\begin{array}{l}\text { The standard "Food safety management systems - Requirements } \\
\text { for any organization in the food chain" includes the following } \\
\text { sections: } \\
\text { 1. Scope of application } \\
\text { 2. Normative references } \\
\text { 3. Terms and definitions } \\
\text { 4. Food Safety Management System } \\
\text { 5. Responsibility of the management } \\
\text { 6. Management of resources } \\
\text { 7. Planning and implementation of safe products } \\
\text { 8. Confirmation, verification and implementation of food safety } \\
\text { management system }\end{array}$ & $\begin{array}{l}\text { It covers all stages of food } \\
\text { production, processing, logistics, } \\
\text { sales. } \\
\text { It is applied in more than } 167 \\
\text { countries of the world. Mostly in } \\
\text { the EU countries as well as in } \\
\text { China, India, Greece, Romania, } \\
\text { Turkey, Russia, Spain, Egypt, } \\
\text { Poland, Ukraine. }\end{array}$ \\
\hline
\end{tabular}




\begin{tabular}{|c|c|c|}
\hline $\begin{array}{c}\text { SQF } \\
\text { Safe Quality Food }\end{array}$ & $\begin{array}{l}\text { The SQF Code is based on the application of the HACCP principles, } \\
\text { and has three levels of certification: } \\
\text { 1) the basis of food safety; } \\
\text { 2) certification of food safety plans based on HACCP; } \\
\text { 3) integrated food quality control and safety systems } \\
\text { The SQF CODE document (7th edition, 2nd level) consists of parts } \\
\text { and modules: } \\
\text { Part A: Implementation and maintenance of the SQF Code } \\
\text { Part B: SQF Code (contains } 16 \text { modules on Good Manufacturing } \\
\text { Practices for each particular industry) }\end{array}$ & $\begin{array}{l}\text { It covers the production of feed, food } \\
\text { products at all stages: primary, } \\
\text { processing, distribution and sales. } \\
\text { It is applied in the USA, Australia, } \\
\text { Canada, Mexico. }\end{array}$ \\
\hline
\end{tabular}

Source: Formed by the authors.

- IFS, FSSC, ISO standards have a high level structure based on the concept of HLS (High Level Structure) which is a common basis for all modern ISO standards which greatly simplifies the integration of several systems simultaneously in the processes: monitoring, action adjustment, audit.

- the main difference between the standards is the modification of the approaches to the implementation of the HACCP principles, the application of their own programs of identification of processes and procedures that allow the results to be corresponded to the set task;

- the GlobalGAP system, unlike the other ones, has a narrow target (for the agricultural sectors: crop and livestock production (including aquatic animals and plants), which provided a detailed description for tracking, a set of indicators for quality and safety, including genetically modified organisms and allergens, however, it is compatible with other BRC, IFS, ISO 9001: 2015;

- each structure has its own organizational, technical and procedural requirements for the certification and licensing of consultants and auditors, accreditation centers, schemes and levels of certification of food safety management systems. For example, to conduct an IFS audit, the company should select a certification body accredited for conducting similar audits. Only IFS certified certification bodies that are accredited by ISO / IEC Guide 65 and who have entered into an IFS agreement may carry out IFS Food audits and issue certificates.

The BRS and IFS standards are very similar, approximately $50 \%$ of IFS requirements fully match BRS requirements, $30 \%$ are partially different, and $20 \%$ of the IFS criteria are not at all present in the BRS. The food safety management system, based on IFS and BRC standards, helps to ensure the quality and safety of products both by suppliers (manufacturers) and retailers. In the European Union, almost $60 \%$ of suppliers of leading retail chains meet the requirements of the IFS standard.

In the context of markets globalization in the analysis of international standards it is expedient to consider their correlation with global safety-related criteria that create additional conditions for the safety of products (Table 2). In particular, it is important for leading EU market companies to apply the standards recognized by the Global Food Safety Initiative (GFSI), provide traceability principles and mechanisms, have unified structural elements, that is, are oriented towards integration with systems: ISO 9001, ISO 14001, OHSAS 18000.
The application of different standards and programs of auditing indicates a high probability of unequal levels of food safety assurance, duplication of audit, increasing costs and complexity for organizations that would seek to meet the requirements of several standards. It is for these reasons that the International Trade Association has created GFSI, a non-profit organization that brings together leading participants in the global food market: retail chains, manufacturers, carriers and other members in the distribution network as well as food safety experts. GFSI's "Certified Once is Known Everywhere" idea is that companies that have been certified to meet one of the standards recognized by the GFSI do not need to be further certified by another recognized organization. The mission of GFSI is to ensure continuous improvement of food safety management systems to ensure confidence in providing safe food to consumers around the world. GFSI is guided by an international trade association called the Consumer Goods Forum which can be a member of any company (What is GFSI. About GFSI).

According to the results of the international standards requirements study all standards provide for the establishment of a tracing system, some of which clearly describe the procedures for product recall, incident management mechanisms. According to the SQF in case of a product recall or an incident involving food hazards, the public must be informed, the company is required to notify the certification body within 24 hours and to provide an action plan within 48 hours.

Tracking systems depend heavily on recording information, mechanisms for storing and authenticating any information. Traceability digital databases require appropriate hardware and software, skilled personnel. The field of animal production is somewhat more difficult to trace than the production of plant products (Aung \& Chang, 2014).

Prerequisite programs (PRP) are generally recognized as a key element without which the food safety system can not function effectively. These are the basic conditions and activities that are necessary to maintain sanitary and hygienic conditions at all stages of the technological processes of food production. Sanitary norms and rules, GMP and GHP are the basic programs on the basis of which programs are developed - the preconditions, and also the food safety management system is implemented. PRP is in the structure of the BRC, IFS Food, Global GAP, SQF standards. For systems based on FSSC 22000 and ISO 22000 standards, additional standards PAS 222, PAS 223, BSI PAS 223, ISO / TS 22002-1: 2009 are applicable for the development, implementation and maintenance of PRP 
programs for specific organizations. These standards complement certain points of the main one, so ISO / TS 22002-2: 2013 details the requirements that are directly related to 7.2.3. ISO 22000: 2005 standard applicable to:

- structures and planning of buildings and engineering systems;

- cleaning and sanitary treatment;

- pest control;

- personal hygiene.

Since September 20, 2016, the application of the prerequisites of the HACCP system in Ukraine is mandatory for all enterprises of the food industry. In order to promote the proper implementation of the prerequisites, taking into account the range of food products, processes and specifics of the individual capacity, the Ministry of Agrarian Policy and Food of Ukraine has approved the requirements for the development, implementation and application of permanent procedures based on the principles of HACCP (Pro zatverdzhennja Vymog shhodo rozrobky..., 2015).

\section{Table 2}

The ratio of international standards to global safety-related criteria

\begin{tabular}{|c|c|c|c|c|c|c|}
\hline $\begin{array}{c}\text { Standards } \backslash \\
\text { safety criteria }\end{array}$ & BRC Food & IFS Food & Global GAP & FSSC 22000 & ISO 22000 & SQF \\
\hline $\begin{array}{l}\text { Application of } \\
\text { HACCP } \\
\text { principles }\end{array}$ & + & + & + & + & + & + \\
\hline $\begin{array}{l}\text { GFSI } \\
\text { Recognition of } \\
\text { the standard }\end{array}$ & + & + & + & + & $\begin{array}{c}\text { Under the } \\
\text { conditions of } \\
\text { application } \\
\text { ISO/TS 22002-1 }\end{array}$ & $\begin{array}{c}\text { The second } \\
\text { level }\end{array}$ \\
\hline Traceability & $\begin{array}{c}\text { Traceability, } \\
\text { section. } 2.13 \\
2.1 .3 .1 \\
2.1 .3 .2 \\
2.1 .3 .3\end{array}$ & $\begin{array}{c}\text { Traceability } \\
\text { system } \\
4.18 .-4.20 \\
\text { 5.9 Management } \\
\text { of incidents, } \\
\text { product } \\
\text { withdrawal, } \\
\text { product recall }\end{array}$ & $\begin{array}{c}\text { Crop Base CB.1 } \\
\text { CB. } 11 \\
\text { All Livestock Base } \\
\text { LB 3 LB 3.1 LB } 3.3 \\
\text { LB } 3.4 \& 3.5 \\
\text { LB } 3.6 \\
\text { LB } 3.7\end{array}$ & $\begin{array}{c}7.9 \\
\text { Traceability } \\
\text { system }\end{array}$ & $\begin{array}{c}7 ., \\
7.4(\mathrm{a}, \mathrm{b}, \mathrm{c}, \mathrm{d}, \mathrm{e}) \\
7.9 \\
\text { Traceability } \\
\text { system }\end{array}$ & $\begin{array}{c}4.6 \text { product } \\
\text { identification, } \mathrm{T} \\
\text { racea\&Recal } \\
4.6 .2 \text { product } \\
\text { Tracea }\end{array}$ \\
\hline $\begin{array}{l}\text { Certificate } \\
\text { validity period }\end{array}$ & 1 year & 1 year & $\begin{array}{l}\text { Options 1a., 1b., 2: } \\
\text { 1year, "recertification } \\
\text { audit" }\end{array}$ & 3 years & $\begin{array}{c}3 \text { years, } \\
\text { Annual audit }\end{array}$ & 1 year \\
\hline $\begin{array}{l}\text { Programs- } \\
\text { prerequisites } \\
(\mathrm{PRP})\end{array}$ & $\begin{array}{l}\text { in the stand- } \\
\text { ard structure }\end{array}$ & $\begin{array}{l}\text { in the standard } \\
\text { structure }\end{array}$ & $\begin{array}{l}\text { in the standard struc- } \\
\text { ture }\end{array}$ & $\begin{array}{l}\text { PAS 222, } \\
\text { PAS 223 } \\
\text { BSI PAS } \\
223 \\
\end{array}$ & $\begin{array}{c}\text { ISO/TS 22002- } \\
1: 2009 \\
\text { ISO/TS } 22002- \\
2: 2013 \\
\end{array}$ & $\begin{array}{l}\text { in the standard } \\
\text { structure }\end{array}$ \\
\hline $\begin{array}{l}\text { Integration with } \\
\text { standards ISO } \\
9001, \\
\text { ISO 14001, } \\
\text { OHSAS } 18000\end{array}$ & $\begin{array}{l}\text { sufficient } \\
\text { level of } \\
\text { integration }\end{array}$ & $\begin{array}{l}\text { simplified } \\
\text { integration level }\end{array}$ & $\begin{array}{l}\text { sufficient level of } \\
\text { integration }\end{array}$ & $\begin{array}{l}\text { simplified } \\
\text { integration } \\
\text { level }\end{array}$ & $\begin{array}{c}\text { simplified } \\
\text { integration level }\end{array}$ & $\begin{array}{l}\text { available with } \\
\text { the third level } \\
\text { of integrated } \\
\text { requirements }\end{array}$ \\
\hline
\end{tabular}

Notes: "+"- active status (yes)

Source: Formed by the authors

In a context of growing competition, food producers and market operators use integrated solutions through the establishment of integrated control systems which gives them a number of advantages: from improvement of management processes to reducing the harmful effects on the environment, improving the safety of the personnel. Integration of system management processes is an affordable solution for organizations of different types of activities and scales; the choice of modules for integration of systems has variability: these may be standards of ISO $9001+$ ISO 22000; ISO $22000+$ ISO 14000+ OHSAS 18001; ISO 9001 + OHSAS 18000 and others. From a number of standards reviewed, the most simplified is the integration of standards ISO, IFS, FSSC because they have a common framework structure. The Global GAP, BRC Food, SQF Level 3 standards are also possible for integration of processes in system management, but the compatibility of processes in audits is somewhat more complex.

\section{Conclusions}

Thus, the standards: BRS, IFS, FSSC 22000, ISO 22000, Global GAP, SQF are a valuable asset to internationally recognized expertise in the management of food safety under the HACCP principles. Obviously, due to the participation of many interested parties in the development of standards, it has been possible to derail the maximum value and benefit from the progressive practice of risk prevention through the control of critical moments in the production of food products, using the results as an opportunity for continuous improvement and safety assurance. 
The results of the study of the international standards requirements and their relation to the global safety performance criteria complement the comprehensive presentation of international experience in food safety management according to the HACCP principles. They are also valuable to food producers, merchant companies and companies entering into an in-depth and comprehensive free trade area with the European Union or other international markets.

As a basis of the standard choice for the implementation of the food safety management system and its certification, there are voluntary principles that are applied to each organization, which determines the decision of the management. It is important to take into account global criteria such as: recognition of the GFSI standard, traceability principles and traceability and prerequisites (PRP), the validity of the certificate, the uniformity of the structural elements and the coherence of processes in the creation of integrated systems with the standards of ISO 9001, ISO 14001, OHSAS 18000.

The survey shows that IFS, BRC, FSSC is the most important in the EU countries, so exporters should implement safety management systems to meet these standards and to confirm compliance with them.

\section{References}

Pro osnovni pryncypy ta vymogy do bezpechnosti ta jakosti harchovyh produktiv. Zakon vid vid 23.12.1997 № 771/97-VR. (redakcija vid 16.01.2020): [Veb-sajt]. Kyi'v, 2020. URL: https://zakon.rada.gov. ua/laws/show/771/97-\%D0\%B2\%D1\%80 (data zvernennja 21.01.2020) (in Ukrainian).

Pro zagal'ni pryncypy i vymogy harchovogo zakonodavstva, Reglament JeS 178/2002 vid 28.01.2002. URL: Www.fsvps.ru/fsvpsdocs/ru/usefulinf/files/es178-2002.pdf (data zvernennja 23.01.2020) (in Ukrainian).

Tolok, G. (2015). Shljahy vprovadzhennja systemy NASSR: ukrai'ns'ki realii'. Prodovol'cha industrija APK, 6, 4-6 (in Ukrainian).

Kushwah, A., \& Kumar, R. (2017). HACCP - ITS NEED AND PRACTICES. Acta Chemica Malaysia, 1(2), 01-05. doi: 10.26480/acmy.02.2017.01.05.

Vorobiov, K., Hurzhii, N., \& Lysenko, M. (2019). Safety of coffee production as the main competitive advantage of the company in the market. Management and ent repreneurship: trends of development, 4(10), 79-93. doi: 10.26661/2522-1566/2019-4/10-07.

Jageljuk, S. V., \& Cydoruk, A. V. (2015). Jevropejs'ki standarty jakosti ta bezpechnosti. Tovaroznavchyj visnyk, 8, 124-129 (in Ukrainian).
Kuzoma, V., \& Pavliuk, S. (2019). Implementation of the Food Safety Management System Based on the Concept of HACCP. Modern Economics, 14(2019), 115-120. doi: 10.31521/modecon.V14(2019)-19.

Himicheva, G. I., Zenkin, M. A., \& Skalyga, T. M. (2015). Analiz suchasnyh pryncypiv i pidhodiv do ocinky jakosti ta bezpechnosti harchovoi' produkcii'. Visnyk KNUTD, 6(92), 156-163 (in Ukrainian).

Hulebak, K. L., \& Schlosser, W. (2002). Hazard analysis and critical control point (HACCP) history and conceptual overview. Risk Anal., 22(3), 547-552. doi: 10.1111/0272-4332.00038.

Shhodo gigijeny harchovyh produktiv. Reglament JeS № 852/2004 vid 29 kvitnja 2004 r. URL: http:/www.fsvps.ru/fsvps-docs/ru/usefulinf/files/es8522004.pdf (data zvernennja 24.01.2020) (in Russian)

About BRC Global Standards. Overview. [Website]. 2018. URL: https:/www.brcglobalstandards.com/ (viewed on: 03.02.2020).

International Featured Standards - IFS [Website]. 2018. URL: https://www.ifs-certification.com/index.php/en/ifs (viewed on: 03.02.2020).

GLOBAL G.A.P. - The Worldwide Standard for Good Agricultural Practices. [Website]. 2018. URL: https://www.globalgap.org (viewed on: 03.02.2020).

Legal status of FSSC 22000. Certified Organizations. [Website]. 2018. URL: http://www.fssc22000.com/ documents/about-us.xml?lang=en (viewed on: 04.02.2020).

ISO/TC 34/SC 17 Management systems for food safety [Website]. 2018. URL: https://committee.iso.org/ home/tc34sc17 (viewed on: 05.02.2020).

ISO 22000 revision Why was ISO 22000 revised? [Website]. 2018. URL: https://www.iso.org/iso22000-revision.html (viewed on: 05.02.2020).

What is GFSI. About GFSI [Website]. 2018. URL: http://www.mygfsi.com (viewed on: 05.02.2020).

Aung, M. M., \& Chang, Y. S. (2014). Traceability in a food supply chain: Safety and quality perspectives. Food Control, 39, 172-184. doi: 10.1016/j.foodcont.2013.11.007.

Pro zatverdzhennja Vymog shhodo rozrobky, vprovadzhennja ta zastosuvannja postijno dijuchyh procedur, zasnovanyh na pryncypah Systemy upravlinnja bezpechnistju harchovyh produktiv (NASSR). Nakaz № 590 vid 1.10.2012. iz zminamy № 429 vid 17.10.2015. Kyi'v: Min-vo agrarnoi' polityky ta prodovol'stva. URL: https://zakon.rada.gov.ua/laws/ show/z1704-12\#n13 (data zvernennja 08.02.2020) (in Ukrainian). 